\title{
Pengujian Kandungan Unsur Hara Pupuk Organik Cair (POC) Limbah Kulit Nenas
}

\author{
Neng Susi, Surtinah, Muhammad Rizal \\ Staf Pengajar Fakultas Pertanian Universitas Lancang Kuning
}

\begin{abstract}
This research was conducted at the Laboratory of Faculty of Agriculture, University of Lancang Kuning. The study was conducted for 3 months from September to November 2015. This study is a descriptive research, where the first process is the process of making organic fertilizer derived from pineapple skin waste fermented for 1 month POC that has been taken samplenya and tested in the laboratory to determine the content of micro and macro nutrients and C-organicnya. To measure macro and micro nutrient content, the test method used was Kjeldahl for nitrogen content, while for $\mathrm{P}, \mathrm{K}, \mathrm{CaO}, \mathrm{MgO}$ and $\mathrm{Fe}$, the Atomic Absobtion spectrophometric (AAS) method was used and the C-organic content was tested by spectrophometric method. The results showed that POC of Pineapple Skin Waste contained P 23,63 ppm, K 08,25 ppm, N 01,27\%, Ca 27,55 ppm, Mg 137,25 ppm, Na 79,52 ppm, Na 79, $52 \mathrm{ppm}, \mathrm{Fe}$ 1,27 ppm, Mn 28,75 ppm, Cu 0,17 ppm, Zn 0,53 ppm and C Organic 3,10\%.
\end{abstract}

Keywords: POC, Pineapple Skin Waste, Nutrient Element

\begin{abstract}
ABSTRAK
Penelitian ini dilaksanakan di Laboratorium Fakultas Pertanian Universitas Lancang Kuning. Penelitian dilaksanakan selama 3 bulan dari bulan September sampai dengan Nopember 2015. Penelitian ini merupakan penelitian diskriptif, dimana proses pertama adalah proses pembuatan pupuk organik yang berasal dari limbah kulit nenas yang difermentasi selama 1 bulan. POC yang sudah jadi diambil samplenya dan diuji di laboratorium untuk mengetahui kandungan unsur hara mikro dan makro serta C-organiknya. Untuk mengukur kandungan unsur hara makro dan mikro, metode uji yang digunakan adalah Kjeldahl untuk kandungan nitrogen sedangkan untuk $\mathrm{P}, \mathrm{K}, \mathrm{CaO}, \mathrm{MgO}$ dan Fe digunakan metode Atomic Absobtion spectrophometric (AAS) dan kandungan C-organik diuji dengan metode spectrophometric. Hasil uji menunjukkan bahwa POC Limbah Kulit Nenas mengandung P 23,63 ppm, K 08,25 ppm, N 01,27 \%, Ca 27,55 ppm, Mg 137,25 ppm, Na 79,52 ppm, Na 79, 52 ppm, Fe 1,27 ppm, Mn 28,75 ppm, Cu 0,17 ppm, Zn 0,53 ppm dan C Organik 3,10\%
\end{abstract}

Kata Kunci : POC, Limbah kulit nenas, Unsur hara

\section{PENDAHULUAN}

Sumber daya lahan memegang peranan penting dalam menentukan pencapaian keberhasilan dalam bidang pertanian. Karena itu berbagai cara dilakukan untuk dapat meningkatkan produktivitas lahan pertanian. Penggunaan pupuk kimia berlebih secara terus-menerus yang diharapkan mampu meningkatkan kesuburan tanah justru menjadi penyebab menurunnya kualitas tanah. 
Keseimbangan unsur hara dapat juga ternganggu karena tidak adanya Pemupukan yang baik harus mengacu pada konsep efektifitas dan efesiensi yang maksimum. Kecermatan dalam menentukan jenis pupuk diwarnai oleh pertimbangan teknis ekonomis, Limbah merupakan bahan yang tidak mempunyai nilai atau tidak berharga lagi. Limbah merupakan permasalahan yang masih sulit untuk dipecahkan namun sepertinya belum terlihat adanya langkah yang kongkrit guna menanggulangi masalah limbah, terutama limbah kulit nenas, konsekuensi dari adanya aktivitas manusia seiring meningkatnya populasi penduduk dan pertumbuhan ekonomi saat ini pengolahan limbah kulit nenas sebagian besar daerah terutama di Desa Kualu Nenas Kec. Tambang Propinsi Kampar Harga pupuk yang semakin tinggi karena pencabutan subsidi dari Pemerintah dan semakin sedikitnya bahan baku pupuk yang harus diimporkan, maka pemanfaatan limbah atau sampah organik menjadi alternatif pengguanaan pupuk Limbah kulit nenas yang sudah tidak bisa dimakan lagi, bisa dimanfaatkan untuk pembuatan POC (Pupuk Organik Cair). Berdasarkan permasalahan tersebut

\section{TINJAUAN PUSTAKA}

Buah nanas (Ananas comosus L. Merr) merupakan salah satu jenis buah yang terdapat di Indonesia, mempunyai penyebaran yang merata. Selain dikonsumsi sebagai buah segar, nanas juga banyak digunakan sebagai bahan baku Berdasarkan kandungan nutriennya, ternyata kulit buah nanas mengandung karbohidrat dan gula yang cukup tinggi. Menurut Wijana, dkk (1991) kulit nanas mengandung 81,72 \% air; $20,87 \%$ serat kasar; $17,53 \%$ karbohidrat; $4,41 \%$ protein dan $13,65 \%$ gula reduksi. Pemupukan bertujuan untuk memelihara atau memperbaiki kesuburan dan memberi zat-zat kepada tanah pengembalian bahan organik tanah.

sehingga pengetahuan teknis tentang fisiologi tanaman, sifat pupuk dan sifat tanah, dimana pupuk akan diaplikasikan sangat menentukan tingkat efesiensi pemupukan

masih menimbulkan permasalahan yang sulit dikendalikan. Timbunan limbah kulit nenas yang tidak terkendalikan yang kemudian berdampak negatif yang akan mempengaruhi berbagai segi kehidupan, baik secara langsung maupun tidak langsung. Pada permasalahan di lingkungan yang menjadi sumber bakteri penyakit, pencemaran udara, tanah, air, dan lebih jauh lagi terjadinya bencana ledakan gas metan, serta pencemaran udara akibat pembakaran terbuka yang menyebabkan pemanasan global.

yang tepat selain juga dapat mengurangi dampak negatif penggunaan pupuk an organic, karena pupuk yang diolah dari limbah atau sampah organik lebih ramah lingkungan.

penulis tertarik melakukan penelitian dengan judul " Pengujian Kandungan Unsur Hara Pupuk Organik Cair (POC) Limbah Kulit Nenas".

industri pertanian. Dari berbagai macam pengolahana nanas seperti keripik, dodol, selai, manisan, sirup, dan lain-lain maka akan didapatkan kulit yang cukup banyak sebagai hasil sampingan.

Mengingat kandungan karbohidrat dan gula yang cukup tinggi tersebut maka kulit nanas memungkinkan untuk dimanfaatkan sebagai bahan baku pembuatan nutrisi tanaman, salah satunya adalah Mikroorganisme lokal (MOL)

langsung maupun tidak langsung menyumbang bahan makanan bagi tanaman. Dengan kata lain pemupukan 
adalah usaha penambahan unsur hara sehingga dapat memperbaiki sifat fisik,Biologi dan kimia tanah sehingga Untuk menghasilkan teknologi yang dapat meningkatkan kesuburan tanah dengan mengurangi penggunaan pupuk kimia buatan telah banyak di lakukan, salah satu teknologi yang saat ini dikembangkan adalah pengelolaan hara terpadu yang mendukung pemupukan organik dan pemanfaatan pupuk hayati. Pemanfaatan mikroorganisme sebagai bahan-bahan perbaikan tanah dalam Pertanian yang berkelanjutan harus memperhatikan 3 aspek utama, yaitu aspek kimia, aspek fisika, dan aspek biologi. Jika hanya bertumpu satu aspek saja, terlebih jika hanya 3 unsur $\mathrm{N}, \mathrm{P}$, dan $\mathrm{K}$ maka berdampak buruk untuk jangka

\section{TUJUAN DAN MANFAAT PENELITIAN}

\section{Tujuan Penelitian}

Adapun tujuan dilakukannya penelitian ini adalah untuk mengetahui

\section{Manfaat Penelitian}

Manfaat dari penelitian ini adalah masyarakat mendapatkan informasi

\section{METODE PENELITIAN}

Penelitian ini merupakan penelitian diskriptif, dimana proses pertama adalah proses pembuatan pupuk organik yang berasal dari limbah kulit nenas yang

\section{Bahan-bahan:}

1. $5 \mathrm{~kg}$ Limbah kulit nenas yang sudah busuk.

2. 10 butir air kelapa

3. $1 \mathrm{~kg}$ gula jawa.

4. Air cucian beras

\section{Cara Pembuatan:}

1. Limbah kulit nenas dihaluskan. Bisa dengan cara ditumbuk atau diparut.

2. Masukkan ke dalam dalam tempat (drum)

3. Tambahkan air kelapa dan air cucian beras.

4. Tambahkan gula.

5. Semua bahan diaduk sampai tercampur merata. sesuai dengan tuntunan tanaman untuk meningkatkan kualitas dan produksi hasil tanaman (Sarif,1986).

meningkatkan ketersediaan unsur hara dalam tanah dan khususnya untuk memperbaiki kesuburan kimia dan biologi pada tanah lahan gambut merupakan alternatif yang tepat, hal ini sejalan dengan kebijakan yang dipilih dalam budidaya tanaman yakni efisiensi energi dan selaras dengan lingkungan (Suriadikarta, Ardi, Simanungkalit, 2006).

panjang, padahal yang dibutuhkan 16 unsur hara dan multihormon. Maka pentingnya untuk kembali bertani ke essensinya, yaitu dengan cara penggunaan pupuk organik dan anorganik yang berimbang (Rachman, 2002).

kandungan hara yang terdapat pada POC limbah kulit nenas

tentang kandungan hara POC limbah kulit nenas

difermentasi selama 1 bulan dengan menggunakan bioaktifator EM4. Cara pembuatan POC adalah sbb: 
6. Tutup drum dengan penutup. Beri lubang untuk aerasi. Lubang aerasi ini bisa menggunakan selang agar tidak dimasukki oleh lalat atau serangga lain.

Semua bahan kemudian difermentasi selama 2 minggu. POC yang sudah jadi diambil samplenya dan diuji di laboratorium untuk mengetahui kandungan unsur hara mikro dan makro serta Corganiknya. Untuk mengukur kandungan unsur hara makro dan mikro, metode uji

\section{HASIL YANG DICAPAI}

\section{Hasil}

Hasil analisa terhadap parameter yang diuji di Laboratorium Perusahaan Kelapa Sawit " Mina Mas Research Centre Tabel: Kandungan Unsur Hara Limbah Kulit Nenas

\begin{tabular}{|c|l|c|c|}
\hline NO & \multicolumn{1}{|c|}{ PARAMETER UJI } & KANDUNGAN & METHODA \\
\hline 1 & Phospat ( ppm ) & 23,63 & Spektrofotometer \\
\hline 2 & Kalium ( ppm ) & 08,25 & AAS \\
\hline 3 & Nitrogen ( \% ) & 01,27 & Destruksi Basah/ Kjedhal \\
\hline 4 & Kalsium /ca ( ppm ) & 27,55 & AAS \\
\hline 5 & Magnesium / Mg ( ppm ) & 137,25 & AAS \\
\hline 6 & Natrium / Na ( ppm ) & 79,52 & AAS \\
\hline 7 & Besi / Fe ( ppm ) & 01,27 & AAS \\
\hline 8 & Mangan / Mn ( ppm ) & 28,75 & AAS \\
\hline 9 & Tembaga / Cu ( ppm ) & 00,17 & AAS \\
\hline 10 & Seng / Zn ( ppm ) & 00,53 & Titrasi \\
\hline 11 & Organik Karbon ( \% ) & 03,10 & \\
\hline
\end{tabular}

\section{Pembahasan}

Hasil yang diperoleh dari analisa terhadap parameter yang diuji terlihat bahwa POC limbah kulit nenas mengandung hara yang dibutuhkan tanaman. Adapun hara yang dikandungnya adalah Phosphat (23,63 ppm), Kalium $(08,25$ ppm), Nitrogen

Tanaman untuk pertumbuhan dan produksinya membutuhkan unsur hara, baik unsur hara makro maupun mikro, diantara unsur hara yang dibutuhkan tanaman adalah Karbon $(\mathrm{C})$, Hidrogen $(\mathrm{H})$, Oksigen (O), Nitrogen $(\mathrm{N})$, Fosfor $(\mathrm{P})$, Kalium (K), Kalsium (Ca), Magnesium yang digunakan adalah Kjeldahl untuk kandungan nitrogen sedangkan untuk $\mathrm{P}, \mathrm{K}$, $\mathrm{CaO}, \mathrm{MgO}$ dan $\mathrm{Fe}$ digunakan metode Atomic absobtion spectrophometric (AAS) dan kandungan $\mathrm{C}$-organik diuji dengan metode spectrophometric.

“ dari Pupuk Organik Cair Limbah Kulit Nenas terdapat pada pada tabel 1 . 
Natrium, Besi, Mangan, Tembaga, Seng

Unsur hara makro yang terdapat pada POC limbah kulit nenas adalah Phospat, Kalium, Nitrogen, Kalsium, dan Magnesium. Phospat bagi tanaman berfungsi untuk pengangkutan energi hasil metabolisme dalam tanaman, merangsang pembungaan, pembuahan, pertumbuhan akar, pembentukan biji, pembelaahan sel tanaman dan memperbesar jaringan sel. Kalium berfungsi dalam proses

Unsur hara mikro yang terdapat pada POC limbah kulit nenas adalah Besi $(\mathrm{Fe})$, Mangan (Mn), Tembaga (Cu) dan Seng (Zn). Fungsi $\mathrm{Fe}$ antara lain sebagai penyusun klorofil, protein, enzim, dan berperanan dalam perkembangan kloroplas, sebagai pelaksana pemindahan electron dalam proses metabolisme. Mn merupakan penyusun ribosom dan juga mengaktifkan polimerase, sintesis protein, karbohidrat. Berperan sebagai activator bagi sejumlah enzim utama dalam siklus krebs, dibutuhkan untuk fungsi fotosintetik yang normal dalam kloroplas,ada indikasi dibutuhkan dalam sintesis klorofil. Fungsi

\section{RENCANA TAHAPAN BERIKUTNYA}

Rencana tahapan berikutnya adalah menginformasikan ke mahasiswa dan masyarakat bahwa POC limbah kulit nenas mengandung unsur hara makro dan mikro serta mengaplikasikan langsung ke

\section{SIMPULAN DAN SARAN}

\section{Simpulan}

Pupuk Organik Cair Limbah Kulit Nenas mengandung unsur hara Phospat, Kalium,

\section{Saran}

Sehubungan dengan banyaknya kandungan unsur hara yang terdapat pada POC dan

Organik

karbon.

fotosintesa, pengangkutan hasil asimilasi, enzim dan mineral, termasuk air, meningkatkan daya tahan atau kekebalan tanaman terhadap penyakit. Nitrogen berfungsi merangsang pertumbuhan tanaman secara keseluruhan, untuk sintesa asam amino dan protein dalam tanaman dan merangsang pertumbuhan vegetatif ( warna hijau ) seperti daun.

$\mathrm{Zn}$ antara lain : pengaktif enim anolase, aldolase, asam oksalat dekarboksilase, lesitimase,sistein desulfihidrase, histidin deaminase, super okside demutase (SOD), dehidrogenase, karbon anhidrase, proteinase dan peptidase. Juga berperan dalam biosintesis auxin, pemanjangan sel dan ruas batang. Fungsi dan peranan $\mathrm{Cu}$ antara lain : mengaktifkan enzim sitokromoksidase, askorbit-oksidase, asam butiratfenolase dan laktase. Berperan dalam metabolisme protein dan karbohidrat, berperan terhadap perkembangan tanaman generatif, berperan terhadap fiksasi $\mathrm{N}$ secara simbiotis dan penyusunan lignin

tanaman. Tanaman pertama yang akan diaplikasikan adalah selada sehubungan dengan adanya penelitian Utama yang didanai oleh APBU Unilak.

Nitrogen, Kalsium, Magnesium, Natrium, Besi, Mangan, $\mathrm{Cu}, \mathrm{Zn}$ dan Karbon

Limbah Kulit Nenas, baik unsur hara makro maupun unsur mikro maka 
dianjurkan agar memakai POC Limbah kulit nenas sebagai pupuk alternatif

DAFTAR PUSTAKA

Anonim, 2004. Klasifikasi Sawi. http://www.plantamor.com/spcdtail .php?. Diakses tanggal 29 Desember 2004.

2008. Klasifikasi Sawi. http://www.plantamor.com/spcdtail .php?. Diakses tanggal 29 Desember 2008.

Arief, 1990. Hortikultura. Penebar Swadaya. Jakarta.

Asti, 2010. Pengaruh Cairan Keong Mas Terhadap Pertumbuhan dan Produksi Padi (Oryza sativa). [Skripsi]. Fakultas Pertanian Pekanbaru: Universitas Lancang Kuning

Ati Prihatiningnur, 2013. Respon Pertumbuhan dan Produksi Tanaman Caisim (Brassica juncea, L) Akibat Pemberian Pupuk Herbafarm. Skripsi Fakultas Pertanian Universitas Lancang Kuning Pekanbaru

Habibi, 2013. Pengujian Mikroorganisme Lokal (MOL) Terhadap sekaligus menyelamatkan lingkungan

$$
\begin{aligned}
& \text { Pertumbuhan dan Produksi Selada } \\
& \text { (Lactuca sativa). Skripsi Fakultas } \\
& \text { Pertanian Universitas Lancang } \\
& \text { Kuning Pekanbaru }
\end{aligned}
$$

Krisno, 2012. Agen Hayati Bacillus sp. http://www.sehatcommunity.com/2 011/06/agens - hayati $s p$. html $\neq$ axzz2arcNLJD. Diakses tanggal 29 Oktober 2012.

Novizan, 2007. Budidaya Tanaman Sawi. http://zuldesains.wordpress.com. Diakses tanggal 12 September 2007.

Pepelakan, 2010. Pengaruh Bakteri Pada Pertumbuhan Tanaman.

Razak, Abdul. 2012. Pengantar Statistik, Malang: Intimedia.

Sukarjo, 2010. Pengaruh Pemberian Mikroorganisme Lokal Nasi Terhadap Pertumbuhan Bibit Karet ( Heved brasilliensis) Stump Mata Tidur. [Skripsi]. Fakultas Pertanian. Universitas Lancang Kuning. Pekanbaru. 